\title{
OBITUARY
}

\section{Dr. G. C. J. Dalton}

IT was with deep regret that atomic energy scientists throughout the world learnt of the death of Dr. G. C. J. Dalton on July 17.

Dr. Dalton was born in Te Awamatu in the centre of the North Island of New Zealand just a little more than forty-five years ago. After a distinguished university career at Auckland and Canterbury University Colleges, Dalton was awarded a Rhodes Scholarship in 1936. At about this time he characteristically played in a major rugby football match while suffering from influenza; in his subsequent weakened condition he contracted poliomyelitis which resulted, after a year's illness, in the loss of the use of one of his legs. This did not deter him, and his strong traits of courage, fortitude and determination enabled him to overcome this physical disability. It did not prevent him from breaking his studies at Oxford to take an active part with the Royal Air Force in the radar defence of Britain, to enjoy rowing at Oxford, tennis at Harwell and swimming in Sydney. These brave and unselfish characteristics again revealed themselves during his fatal illness when he continued his work long beyond the time when he could humanly or medically be expected to do so.
Dalton claimed that as the engineer had to design equipment to operate, "he had to know his physics better than the physicist". Dalton himself certainly showed a penetrating and critical approach to the basic scientific problems, and his mastery of these, coupled with his considerable mathematical ability, enabled him to make major contributions to both research and teaching in the newer engineering developments, such as atomic energy.

These broad scientific interests coupled with a critical and imaginative mind showed themselves to full advantage in his initiation of the fast reactor programme at Harwell, in academic life as dean of the Faculty of Engineering in the University of Auckland, in the formulation of the Australian hightemperature gas-cooled reactor programme, and from 1960 as director of the Australian Atomic Energy Research Establishment.

To quote Sir Mark Oliphant: "Dr. Dalton was a warm friend of all who thought about the new ideas in engineering, helpful and generous of his time and effort, inspiring to young and old, and completely devoted to his work, his family and his ideals".

His loss is indeed a grievous one to Australia, to atomic energy and to his many friends and colleagues scattered throughout the Western world.

C. N. Watson-Munro

\section{NEWS and VIEWS}

New Appointments at Associated Electrical Indus-
tries, Ltd. : Mr. L. J. Davies, C.B.E.

MR. I. J. DAvies has recently been made responsible for the direct supervision of the four Research Establishments of Associated Electrical Industries, Ltd, at Aldermaston, Harlow, Manchester and Rugby. Mr. Davies was educated at Oxford, going there with an open exhibition in natural science, taking his first degree and carrying out postgraduate work, joining British Thomson-Houston Co., Ltd., in 1924. For the past sixteen years he has been director of research at Associated Electrical Industries (Rugby), Ltd. During this period, under his guidance, many changes have been made in the scope and nature of the work and in the laboratory buildings, culminating in the setting up and occupation last year of completely new buildings on an eight-acre site reserved for research. For a period his interests were concerned with lamps and lighting. He was closely connected with the introduction into Britain of the fluorescent lamp and in a form that made it suitable for production for factory lighting during the Second World War. He was awarded in 1942 (with co-authors) the Crompton Premium of the Institution of Electrical Engineers for a paper on this subject. $\mathrm{He}$ is a past president of the Illuminating Engineering Society, a member of Council of the British Electrical and Allied Industries Research Association, and chairman of the Board of Governors of Rugby College of Engineering Technology. He was twice Faraday lecturer of the Institution of Electrical Engineers, and was made C.B.E. in 1960 .

\section{Dr. J. E. Stanworth}

Dr. J. E. STANworth has been appointed as director of research of Associated Electrical Industries, Ltd., in succession to Mr. L. J. Davies. Dr. Stanworth is a native of Lancashire, and was initially educated at Nelson Secondary School, from which he went to the University of Sheffield to gain a B.Sc. (Tech.) degree with honours in 1935 and his M.Se. (Tech.) degree in 1937. He joined the British ThomsonHouston Co. as glass technologist in 1937. He spent his first years at Rugby in research on glasses and on glass structure, eventually leading a team on this subject partly in the research laboratory and partly in the glass works of the Company. He then took over wider duties involving the supervision of the research of a large number of groups engaged in investigating new materials and their applications, particularly in the fields of semiconductors, materials for nuclear power reactors, lamps, high-temperature materials and hard materials. Dr. Stanworth was awarded the degree of D.Sc.(Tech.) by Sheffield in 1958. $\mathrm{He}$ is a Fellow of the Royal Institute of Chemistry, the Institute of Physics and the Physical Society, and the Society of Glass Technology.

\section{Medical Research Council:}

New Members

Prot. M. L. Rosenheim (professor of medicine in the University of London at University College Hospital Medical School) and Prof. Wilson Smith (lately professor of bacteriology in the University of London 